Research Based Article

\title{
KONSELING FITRI: MODEL KONSELING BERBASIS JUZ QURANI
}

\author{
Lutfi Fauzan * \\ Universitas Negeri Malang
}

\begin{abstract}
FITRI COUNSELING: JUZ QURANIC-BASED ON COUNSELING MODEL. Al-Qur'an as holly book that has scientific content can be revealed about human being with all their potencies and their differencies individual characters. The revealing scientific treasure is approached by Bayani method, Ifani, Burhani and $\mathrm{HAQ}$ mehod. The result shows that human has five natural (fitri) potencies, and has individual differencies, they are 30 personality types as like as quantity of Al-Qur'an juz. Developing human personality should be applied based on the character difference. Therefore, the juz qurani-based on idea and counseling model was made. The counseling model has five main stage and some specific behavior change techniques.
\end{abstract}

KEYWORDS: Counseling, Juzuziyah, Qurani.

* Corresponding Author: Jurusan Bimbingan dan Konseling, Fakultas Ilmu Pendidikan Universitas Negeri Malang; Jalan Semarang No. 5, Sumbersari, Kec. Lowokwaru, Kota Malang, Jawa Timur, Indonesia 65145; Email: lutfi.fauzan.fip@um.ac.id

Permalink: http://ijec.ejournal.id/index.php/counseling/article/view/23

How to cite (APA): Fauzan, L. (2018). Konseling fitri: Model konseling berbasis juz qurani. Indonesian Journal of Educational Counseling, 2(1), 69-86.

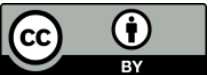

This is an open access article distributed under the terms of the Creative Commons Attribution 4.0 Internationa License, which permits unrestricted use, distribution, and reproduction in any medium, provided the origina work is properly cited. @ 2018, Lutfi Fauzan.

\section{PENDAHULUAN}

Berbagai kajian dalam ragam paradigma dan aneka sudut pandang tentang manusia, dalam sejarah dan perkembangan keilmuan, belum sampai pada tingkat yang memuaskan. Sejauh ini, setiap upaya menyibak kesejatian manusia hampir selalu ditemukan celah kekurangan, yaitu misteri yang belum terjawab. Ini merupakan permasalahan keilmuan tentang manusia. Dapat dikata upaya manusia memahami dirinya belum menjangkau pada kebenaran haqiqi, sekalipun uraian yang dikemukakan pemikir bertemakan hakikat manusia. Kegagalan manusia memahami realitas, termasuk dirinya, terjadi karena manusia mendasarkan pemikiran pada paradigma usang. Pilihan terhadap paradigma ini telah melahirkan krisis kompleks multidimensional, yang mencakup dimensi intelektual, moral, dan spiritual (Capra, 1999). 
Berbagai pemikiran tentang manusia dan pengembangannya pada umumnya belum meliput totalitas kehakikiannya. Semenjak zaman pergerakan pemikiran Thales yang berusaha mengaitkan manusia dengan dinamika alam sampai dengan peradaban Meso Amerika dan hingga kini pada umumnya belum cukup membukakan keseluruhan kesadaran tentang manusia. Hal ini disebabkan setiap teori tentang manusia memiliki semangat dan maksud tertentu dan dalam perspektif tertentu. Alhasil, yang tersajikan adalah sejumlah kelebihan yang bergandeng dengan kelemahan dari teori yang ada ketika diinteraksikan dengan realitas sosial (Yahdi, 2010).

Dalam tinjauan filsafat ilmu, permasalahan pokok dalam pemikiran tentang manusia adalah bagaimana kita mengetahui bahwa konsepsi tentang manusia yang beraneka ragam itu benar atau salah, lengkap atau tidak lengkap? Permasalahan berikutnya adalah bagaimana kita mengetahui bahwa ilmu pengetahuan tentang konsepsi manusia seutuhnya tersebut runtut atau tidak runtut? Kedua permasalahan tersebut muncul karena menurut Teorema Goedel - Weisskopf atau hukum dasar kepeniadaan II dinyatakan "mustahil ilmu pengetahuan bisa membenarkan dirinya". Hal itu berarti kebenaran ilmiah harus dicari dari luar ilmu pengetahuan, misalnya filsafat. Namun demikian, filsafat pun tidak bisa membenarkan dirinya sendiri, karena secara definitif salah satu karakter filsafat itu spekulatif. Oleh karena itu, kebenaran filsafat hanya bisa ditentukan pada tataran ilmu yang lebih tinggi, yakni agama. Dengan demikian, agama merupakan validator tertinggi terhadap kebenaran filsafat dan kebenaran ilmiah. Selain itu fungsi ajaran agama juga sebagai landasan aksiomatika dalam pengembangan ilmu (Thoha, 2004).

Memahami manusia semestinya dilandasi oleh suatu keyakinan bahwa manusia (mikrokosmos) dan masyarakat (makrokosmos) merupakan ayat-ayat (simbol, pertanda, lambang) kebesaran Allah Swt. yang tertulis dalam alam semesta atau sering disebut dengan ayat-ayat kauniyah. Ayat-ayat Allah yang lain tertulis dalam Kitab Suci, salah satunya Al-Quran, sebagai Perjanjian Terakhir yang berisi ayat-ayat qauliyah. Oleh karena kesemuanya merupakan ayat-ayat Allah, maka mustahil ada pertentangan antara ayat-ayat qauliyah yang tertulis dalam Kitab Suci Al-Quran dengan ayat-ayat kauniyah yang terdapat pada manusia dan masyarakat serta alam semesta. Dengan demikian, pasti ada benang merah yang dapat ditarik dari AI-Quran pada manusia dan ilmu-ilmu perilaku (behavior sciences). Tinggal bagaimana penelusuran dan penuangan pemahaman tentang manusia yang berakar dari kayakinan dan nilai agama itu digelar dengan memenuhi kriteria kaidah filsafat ilmu yakni ontologi, epistemologi, dan aksiologi (Thoha, 2004). 
Islam diyakini oleh para pemeluknya sebagai ajaran yang komplit, meliputi segala aspek, baik duniawi maupun ukhrawi, baik mengenai Tuhan, manusia, maupun alam semesta, bahkan makhluk gaib seperti malaikat, jin, syurga, dan neraka. Khusus mengenai manusia, Al-Quran dan Al-Hadits juga banyak membahas masalah ini. Namun demikian, pemahaman umat terhadap konsepsi manusia dalam Islam tentu berbeda-beda, tergantung pada kemampuan intelektual umat, terutama para cendekiawannya. Dalam pandangan ahli makrifat, dipengaruhi kemampuan kasyaf (menyibak rahasia yang tersembunyi) yang dianugerahkan oleh yang Mahaberilmu. Oleh karena itu, terjadi variasi pemahaman di antara cendekiawan Muslim terhadap konsepsi manusia dalam Islam. Namun itu bukan merupakan suatu kesalahan. Variasi itu lebih terjadi karena perbedaan luas atu sempitnya sobekan pintu hijab hati mereka, sebagian lagi dipengaruhi oleh tingkat perkembangan berpikir penganutnya.

Berkembangnya ilmu yang luar biasa pada abad pertengahan pada masyarakat Muslim dimotivasi oleh semangat berketaan pada agama, dan bukannya kebencian dan pemisahan diri dari agama. Dengan semangat itu telah dihasilkan khazanah ilmu yang luar biasa unggul baik dalam tataran teori maupun praktik (sebelum warisan buku-buku dan manuskrip yang ada dihancurkan oleh Khubilai Khan). Oleh karena itu menggali keilmuan dari kitab suci bukanlah pilihan yang rendah, bahkan semakin mendekatkan pemahaman pada hakiki kebenaran, menggali ilmu dari Al-Quran sesungguhnya lebih menjanjikan dan lebih kuat hujjah-nya (argumentasinya). Lalu bagaimana galian keilmuan Al-Quran mengenai manusia dengan segala potensinya itu? Selanjutnya bagaimana model pengembangannya, khususnya melalui konseling? Tulisan awal yang singkat ini diharapkan menyediakan sedikit jawaban mengenai permasalahan ini.

\section{METODE}

Tuangan tulisan ini merupakan singkapan dari keilmuan qurani yang pada dasarnya menerapkan tiga hampiran secara terpadu, yaitu bayani, irfani, dan burhani. Metode bayani yang dipilih adalah bayani al-kitabi dengan menelaah tulisan ulama yang bertemakan manusia dengan potensi fitriyah dan juz pribadinya. Dalam telaah kitab ini difokuskan pada sejumlah tulisan Ki Moenadi yang bertemakan potensi manusia dan juz pribadi. Bahan telaah khususnya difokuskan pada buku yang berjudul: keilmuan pasti juz tertentu (bagian 1 dan 2) (2000); pengembangan potensi manusia (1999); ukuran pasti kepribadian manusia (2000); menimba pelajaran ke dalam diri manusia (1998); pendidikan terpadu bersifat qurani (1998); dan butir-butir keilmuan qurani (1997). Kesemuanya ditelaah melalui analisis isi untuk mendapatkan simpulan 
menyeluruh tentang manusia dengan potensi dan juznya (sebagai perbandingan, ditelaah pula tulisan Imam Ghazali tentang manusia).

Tulisan Ki Moenadi M.S. yang ditelaah ini pada dasarnya merupakan hasil dari pengembangan keilmuan yang memadukan metode irfani dan burhani. Metode irfani, yaitu keilmuan qurani yang disingkapkan melalui proses riyadhah dan tafakur yang didasari tiga keyakinan dasar, yaitu: 1) Allah Yang Maha Pemurah yang mengajarkan Al-Quran dan memberikan penjelasan, maka manusia tinggal meminta kepada-Nya (QS. Ar-Rahman 1-4). 2). Kepada orang yang memurnikan iman dipastikan Allah mengirimkan berita keilhaman (QS. AtTaghabun 11). 3) Dengan menempuh jalan taqwa maka Allah memberikan pengajaran kepadanya (Al-Baqarah 282). Dari proses tersebut telah dihasilkan suatu metode pengembangan keilmuan yang disebut timbaan makna dari HurufAngka-Quran (metode HAQ). Sedangkan metode burhani merupakan cara menemupastikan kebenaran dengan data empiris, sehingga diperoleh sinkronisasi antara hasil irfani dengan fakta-fakta dan kebenaran yang melekat pada manusia secara empiris.

Melengkapi metode di atas, penulis melanjutkan pengembangan, khususnya untuk memperoleh model pengembangan manusia melalui konseling berbasis juz. Metode yang digunakan adalah analisis huruf dan angka qurani (metode HAQ), yang merupakan usaha pendalaman atas simbol ayat-ayat AlQuran. Telaah bukan sebatas penemuan makna dari rangkaian kata dan kalimat, melainkan menyangkut fonomena yang tertuang pada Mushhaf Al-Quran standar Mushhaf Utsmani. Fenomena mushhaf yang dimaksud mencakup huruf-huruf dengan makna dan padanan angkanya (seperti alif = 1; ba' = 2; tak = $3 \mathrm{dst}$ ), garis, titik, tanda sakal, rukuk (ruk'ah), getaran bunyi, sampai dengan format penulisan mushhaf. Selain itu pengembangan gagasan juga diperoleh melalui operasi aritmatika bilangan qurani, berupa penambahan, pengurangan, perkalian, dan pembagian nilai huruf Al-Quran.

\section{HASIL DAN PEMBAHASAN}

Pada bagian ini berturut-turut dibahas: keyakinan dasar keilmuan, manusia dengan struktur potensi fithri dan perjalanan jiwanya melalui tahapan-tahapan menuju kesempurnaan, manusia dengan perbedaan individual berdasarkan juz pribadinya, dan model konseling berbasis juz pribadi manusia.

\section{Keyakinan Dasar}

Al-Qur'an adalah Firman Allah sebagai gelaran ayat-ayat qauliyah, yang pada dasarnya merupakan idea Allah atau cetak biru dari alam semesta. Oleh karena itu Al-Qur'an berisi berita lengkap mengenai unsur-unsur alam semesta 
dan dinamika kehidupannya, baik yang bersangkutan dengan alam gaib maupun alam nyata. Manusia termasuk di dalamnya, bahkan informasi tentang manusia paling banyak disajikan dibandingkan dengan unsur alam semesta lainnya.

Manusia merupakan bagian ayat-ayat kauniyah sebagai perwujudan dari idea Allah (ayat qauliyah). Dengan demikian menjadi masuk aqal ketika didapati keselarasan (sinkronisasi) antara zhahir dan makna qauliyah qurani dengan haqiqi alam semesta, khususnya manusia. Bahkan dalam kedudukannya sebagai khalifah, manusia menjadi pusat dan padatan (mikrokosmos) dari keberadaan alam semesta (makrokosmos).

Al-Qur'an qauliyah secara haqiqi tertulis dalam guratan pena ghaib dan tersimpan di Lauhil Mahfuzh, dan representasi di alam duniawi tertulis dan terformat di dalam mushhaf. Baku mushhaf yang disepakati para sahabat yang dalam bimbingan dan petunjuk-Nya (ar-rasyidin-al-mahdiyin) adalah Mushhaf Utsmani.

Mushhaf Utsmani memiiliki kekhasan, di antaranya penulisan Al-Qur'an dibagi ke dalam 30 juzu'. Pada setiap juz terdiri atas satu atau lebih surat dengan karakter yang khas atau memiliki keunikan tersendiri, di samping sejumlah karakter juz yang bersifat umum.

Di sisi lain, bukti nyata menunjukkan manusia pun memiliki kekhasan karakter yang membedakan satu dengan lainnya, di samping sifat-sifat keumumannya. Perbedaan karakter manusia tersebut ternyata selaras dengan perbedaan karakter format Al-Qur'an Mushhaf Utsmani. Dengan demikian kalau mushhaf terdiri atas 30 juz, maka manusia juga memiliki ragam kekhasan (semacam tipologi) sebanyak 30 . Dengan perkataan lain, setiap manusia memiliki juz pribadi, berupa 1 juz dari antara 30 juz yang ada.

Juz pribadi manusia merupakan rancangan ketetapan dan ukuran pasti (qadar) kepribadian manusia, yang menentukan corak sifat-perilaku, pola pandang, jalan hidup, kekuatan, kelemahan, dan capaian yang bisa diharap berdasarkan ketentuan juznya. Dengan begitu pembinaan manusia menuju kesempurnaan dalam proses kehidupannya perlu didasari oleh juz pribadi yang merupakan batasan jati dirinya.

Pembinaan manusia dialamatkan pada segi jasmaniah (mencakup 13 titik energitisnya: otak/kepala, mata, THT, rangka tulang, tangan, kulit/syaraf, paruparu, jantung/darah, hati/liver, perut, sistem kesetimbangan, alat vital, dan kaki), dan ruhaniah (menyangkut 5 titik potensi fithrahnya: ruh, rasa, hati, aqal, dan nafsu). Pembinaan pada segi jasmaniah mengarah pada pertumbuhan tubuh yang sehat dan kuat (SK). Pembinaan ruhaniah mengarah pada penjadian jiwa yang cerdik dan cerdas (CC). Perpaduan pembinaan keduanya menjadikan 
manusia tumbuh selaras berjenjang naik mencapai derajat insan kamil dengan ciri cerdik-cerdas-sehat-kuat (CCSK).

Secara khusus, pembinaan manusia ditempuh melalui proses pendidikan, yang salah satu strateginya dapat didekati dengan konseling, sehingga konseling yang diperlukan pun hendaknya berpijak pada juz pribadi. Untuk itu konseling berbasis juz qurani dikembangkan atas dasar pemahaman juz pribadi manusia.

\section{Potensi dan Tujuan Perjalanan Hidup Manusia}

Dalam diri manusia terdapat suatu daya atau ketenagaan, yang haqiqat seluruh kegiatan jiwa dan raga manusia berpusat pada rajutan ketenagaan di dalam diri ini. Ketenagaan yang merupakan potensi fithri ini dapat digali dan dikembangkan serta didayamanfaatkan. Bagaimana pengetahuan manusia tentang potensi dirinya akan menentukan sikap dan perbuatan dalam pengembangan dan pendayamanfaatannya (Ki Moenadi, 1999).

Imam Al-Ghazali (1058-1111 M) berdasarkan pemahamannya atas AlQur'an memberikan gambaran tentang manusia sebagai makhluk jasmani dan rohani atau tubuh dan ruh. Ada interaksi kuat antara ruh dan tubuh. Hubungan antara keduanya tidak terjadi secara spesifik melainkan secara keseluruhan. Ruhani manusia terdiri atas empat unsur yaitu: 1) qalb (hati); 2) ruh (roh dan jiwa); 3) nafs (nafsu), dan 4) `aql (akal pikiran atau inteligensia).

Pemikir sepeninggal Al-Ghazali pada umumnya mengikuti pandangan tersebut. Hanya di Indonesia, pada akhir abad 20 muncul seorang pemikir yang pandangannya lebih menyempurnakan pandangan Al-Ghazali, yakni Ki Moenadi (1940-2007). Pandangan-pandangannya banyak dituangkan pada buku-buku yang telah diterbitkan (lebih dari 70 judul), dan manuskrip yang belum diterbitkan. Sebagian manuskripnya diolah dan diterbitkan pada dunia maya oleh seorang pengikutnya (Taufiq Thoyib, 1958-2013) pada webblog Kajianbudayailmu. Bisa jadi pandangan Ki Moenadi yang merupakan galian keilmuan qurani tersebut merupakan alternatif untuk mengganti pandangan usang (trikotomi) dalam membidik unsur dan fungsi potensi manusiawi yang sudah terbukti gagal mengentaskan manusia dari keterpurukannya.

Melalui keyakinan dan proses pendekatan kepada Yang Mahaberilmu itu, Ki Moenadi, M.S.mengungkapkan bahwa manusia itu mempunyai 5• (baca: lima titik) unsur potensi ketenagaan yang terdiri atas: (1) unsur Ketenagaan ruh (ruhul quddus); (2) unsur Ketenagaan rasa (dzauqun); (3) unsur Ketenagaan hati (qalbun); (4) unsur Ketenagaan aqal (aqlun); (5) unsur Ketenagaan nafsu (nafsun). Ke 5 potensi itu dapat digambarkan strukturnya seperti gambar 1 


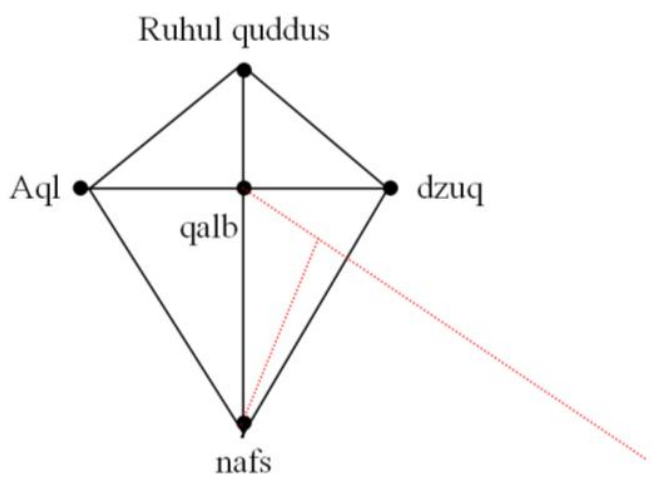

Gambar 1. 5 Titik Potensi Ketenagaan Manusia

Ke-5 unsur ketenagaan atau potensi dalam diri manusia mempunyai fungsi dan pengembangan yang berbeda-beda, meskipun demikian tetap utuh bersatu dalam rajutan ketenagaan Ilahiah, di antara setiap titik ada tali hubungnya. Adapun tali halus (titik-titik lembut) merupakan tali pengendali agar semua titik dalam pertumbuhan dan perkembangannya tidak lepas dari kaidah-kaidah yang ditetapkan Allah. Adapun fungsi dan pengembangannya sebagai berikut:

Ruh merupakan bagian yang paling awal ada dan telah mengenal Rabbnya sebelum dipersatukan dengan tubuh manusia. Posisi ruh dalam struktur potensi berada pada bagian terdepan karena ia berfungsi menerobos lapisan-lapisan cahaya Allah yang melindungi guratan papan Lauhil-Mahfudz. Dengan memelihara tali hubung dengan Allah dan pengembangan laku bercinta-mesra dengan Allah dan tanggung jawab membimbing ke $4 \cdot$ unsur potensi lainnya, ruh melaksanakan tugas memimpin dan menggandeng unsur potensi lainnya dalam kebersamaan perjalanan, ibarat ganggang-air yang terajut menjadi satu keterikatan secara keseluruhannya.

Rasa memiliki pola gerak lompat yang cepat, begitu cepatnya terkadang sulit diikuti dan difahami oleh aqal. Rasa berfungsi untuk menikmati keindahan sifat Allah sekaligus menikmati segala kasih-sayang/kepemurahan Allah. Rasa ini baru dapat berfungsi setelah ruh berhasil menerobos lapisan-lapisan cahaya Allah. Perkembangan lanjut adalah membentuk sikap perilaku yang indah, keilmuan yang indah serta pola hidup yang indah. Kemudian kepemurahan Allah yang telah dirasa itu dikirimkan kepada hati.

Hati selaku wadah penerima getaran pengkhabaran dari Allah. Pengkhabaran dari Allah itu diperoleh hati melalui getaran rasa dan persambungan tali ruh. Pengembangan hati diperoleh melaluii kerja sama yang baik antara ruh, rasa dan hati yang titik sasaran pengembangannya adalah dunia spiritual, Hati yang bersih dapat menangkap pemberitaan secara benar, sedangkan yang kotor mudah salah mengerti. Oleh karena itu hati menjadi 
penentu apakah seseorang dalam perjalananya akan berada tetap dalam kelurusan kebenaran ataukah menyimpang. Lurus atau menyimpangnya itu dapat diketahui dari bagaimana bekerjanya aqal, karena langkah lanjut yang dilakukan hati setelah menangkap getaran rasa dan ruh adalah meneruskannya kepada aqal.

Aqal berfungsi menata bahasa getaran sebagai informasi yang ditangkap oleh wadah hati. Maksud aqal menata bahasa getaran untuk diolah sebagai informasi agar mudah dimengerti, dikomunikasikan pada sesama dan bisa diwujudkan pada perilaku. Pengembangan aqal adalah menghantarkan manusia pada jenjang keintelektualan yang indah. Yaitu intelektual yang laras-lurus dengan kehendak Allah. Namun aqal ini ibarat komputer, apabila memperoleh data yang benar dari hati maka hasilnya bagus. Sebaliknya kalau ia hanya menerima sampah maka hasil dari proses oleh lanjutnya juga sampah.

Nafsu merupakan bagian pelaksana. la berfungsi mengikuti apa-apa yang telah ditata oleh aqal dengan pengembangannya adalah hidup lurus-terkendali dalam rambu-rambu ketentuan Allah. Pengembanan tugas demikian itu hanya terjadi apabila nafsu terbina melampaui nafsu muthmainah (yang tenang). Sebaliknya nafsu yang tidak terkendali akan menguasai dan merusak jalannya 4• potensi lainnya. Ruh akan dipenjara sehingga tidak lagi bebas merdeka untuk berjumpa Rabbnya. Rasa diganggu sehingga jalan lompatannya cenderung mengambil jalan yang menceng atau menyimpang. Hati dikotori sehingga sulit menerima dan membedakan isyarat sebagai informasi yang baik ataukah buruk. Aqal yang menerima informasi yang tidak jelas dan bernilai sampah dari hati akan mengolah lanjut dan membuat simpulan-simpulan yang merusak kesetimbangan diri dan semesta. Wujud nyatanya adalah ilmu dan teknologi yang berdampak merusak lingkungan semesta. Nafsu yang tidak tertata juga akan menutup pertumbuhan aqal dan menggantikannya dengan logika --- logika dan aqal bekerja sama-sama dalam ranah berfikir namun berbeda dalam esensinya karena logika didasari kepentingan diri sedangkan aqal merenung fikir didasari ketaatan pada Pencipta dengan hasil penyaksian akan Kemahabesaran-Nya.

\section{Perkembangan Nafsu}

Pengembangan terhadap titik potensi dalam sinergi kerja terpadu ruh, rasa, hati akan membawa seseorang masuk menerjuni dunia dimensi 3 dan seterusnya. Sedangkan pengembangan terhadap rasa, hati, aqal dalam sinergi terpadunya akan membawa seseorang membumbung tinggi di kerajaan ilmu Allah (suatu capaian yang menjadikan seseorang bukan lagi mencari ilmu melainkan diberi ilmu langsung oleh Yang Maha Berilmu). Keadaan itu dapat terjadikan ketika setiap unsur potensi bersedia dialiri ketenagaan Ilahiyah dan dikembangkan sesuai dengan fithrahnya. Hanya saja satu-satunya unsur dalam 
diri manusia yang enggan diisi ketenagaan Ilaahiyah adalah nafsu. Meskipun pada haqiqinya seluruh unsur daya-potensi ketenagaan di dalam diri manusia berbobotkan ketenagaan Ilaahiyah, namun nafsu cenderung menyediakan diri diisi ketenagaan syaithaniyah, kecuali jika nafsu tersebut sudah dalam keadaan dirahmati (Ki Moenadi, 2000). Oleh karena itu pendidikan terhadap manusia harus terindikasikan pada perubahan nafsu ke tahapan atau maqam yang lebih utama.

Pendidikan terhadap nafsu perlu diberikan secara benar dan dengan perhatian khusus agar dapat memudahkan pertumbuhan dan perkembangan alami atau fithriyah dari unsur potensi lainnya. Pembinaan unsur potensi di luar nafsu juga diperlukan, hanya saja hasil pendidikannya mudah teracak-acak kembali ketika nafsu belum ditundukkan dan tertata. Apabila nafsu terbina dengan baik, maka unsur potensi lainnya akan mudah dibina dan dikembangkan.

Pendidikan terhadap nafsu mutlak diperlukan, karena nafsu merupakan unsur liar dalam diri manusia, sifat dasarnya cenderung pada keburukan. Sungguh pun begitu, sejalan dengan pertumbuhannya dapat berkembang menjadi baik dan indah, karena nafsu ini juga menjadi jiwa manusia. Tumbuhkembang nafsu menuju kesempurnaan kejadiaanya berproses melalui 7 tahapan. Oleh karena itu upaya ke arah pengembangan atau pendidikan juga perlu disesuaikan dengan tingkat perkembangannya. Adapun tujuh tahap perkembangan nafsu itu adalah: ammarah, lawwamah, muthmainnah, mulhamah, radhiyah, mardhiyah, dan kamilah.

\section{Tahapan Ammarah}

Tahapan nafsu yang perilakunya condong pada keburukan sehingga hati menjadi tertutup. Tahapan ini diibaratkan keberadaan emas di tengah-tengah batu dan pasir, sepintas tidak terlihat bahwa di dalamnya tertimbun emas. Itulah gambaran hati manusia di tengah-tengah kekerasan hidup. Hati manusia pun ikut-ikut dipenuhi bentuk-bentuk kekerasan, bercampur-aduk dalam diri unsur kebathilan dengan keburukan/kejahatan. Tidak jarang keburukan-kejahatan lebih menonjol di dalam diri, seakan-akan sudah tidak ada lagi kebaikan yang dapat ditampilkan, karena kebaikan (kebenaran) telah terselimut oleh keburukan (kebathilan). Gambaran bahwa kebathilan lebih banyak ditampilkan daripada kebaikan (kebenaran), sejak dari sikap perilaku hingga ilmu yang disajikan, semuanya kebathilan.

Pendidikan yang diperlukan adalah penumbuhan kesadaran melalui penyajian berita kebenaran secara terus menerus, dan pembenturan dengan akibat-akibat perbuatan yang dapat membuat kekerasan menjadi melunak dan mengakui dosa kesalahannya, sehingga dapat diambil nilai keindahannya. Ibaratnya, setelah bongkahan batu terpecah atau tumpukan pasir digali, barulah 
dapat diketahui bahwa di antara batu itu ada emasnya, yaitu hati dengan potensi cahayanya.

\section{Tahapan Lawwamah}

Ini merupakan tahapan nafsu yang menyesali diri. Tahapan ini diibaratkan setelah bongkahan batu yang berisi emas dipecah, kemudian dibawa pulang ke rumah, diolah-lanjut dengan dipecah-halus, agar terpisah batu dengan emas. Itulah gambaran proses naik ke tangga kedua (di lawwamah) yang tidak mudah, lewat pertarungan nyawa, yang bisa saja ditodong dan dirampok di tengah jalan oleh penyamun. Sekalipun nyawa taruhannya: "Apakah si penambang akan mundur?" Tidak! Sebaliknya (seharusnya) semakin nekat mempertahankan bawaannya, berupa pecahan batu yang di dalamnya terdapat emas. Begitu pula hati manusia. Setelah dosa-dusta diketahui lewat pengakuan, ternyata dosadusta masih menyatu di dalam hati. Pemukulan dosa-dusta, masih dilakukan agar terpisah antara salah (bathil) dengan benar (haq). Dosa-dusta di hati dipisahkan melalui suatu proses penyaringan, sebagaimana emas melalui tahapan pendulangan. Proses ini untuk masuk tahapan ke-3 (muthmainnah).

Di wilayah lawwamah (jenjang ke-2), seseorang mulai mengerti dosa-dusta dan sudah dapat membedakan antara haq dengan bathil. Tetapi ketidakkuatan menghadapi rampokan-todongan iblis, sering jatuh-bangun di wilayah lawwamah. Laksana seorang penambang emas, yang jatuh-bangun (berkelahi) menghadapi si penyamun.

\section{Tahapan Muthmainnah}

Pada tahapan ini nafsu mulai mendapatkan ketenangan. Tahapan ini diibaratkan seperti saat memecah halus bongkahan batu, sesudah itu tampak jelas di dalamnya ada butiran emas. Tampak nyata pula dosa-dusta/kebathilan, naiklah tahapan penyaringan pada setiap laku perbuatannya. Pada tahapan ke3 ini mulai dirasakan kenyamanan, tidak sebagaimana wilayah lawwamah yang selalu ditodong dan dihadang oleh iblis. Salah satu bentuk penyaringan adalah dibukakan-Nya pintu taubat, dan ditinggalkan segala bentuk kebathilan, geraklangkah mulai diupayakan mengikuti isyarat hati yang sudah mulai bersih.

\section{Tahapan Mulhammah}

Tahapan penerimaan pesan-pesan kebenaran. Tahapan ini ibarat setelah emas disaring (dipisahkan dari pasir dan batu) naik proses berikutnya yaitu proses pencetakan emas menjadi emas batangan murni, tanpa campuran batu dan pasir. Proses tahapan ke-4 (mulhamah), yaitu hati sudah terpisah dari dosadusta atau kebathilan. Artinya nafsu tidak mengganggu hati untuk menerima kebenaran. Pada proses pencetakan menjadi emas batangan ini, emas sudah mulai dapat dipasarkan. Emas atau keilmuan hati yang dipasarkan atau 
disebarkan kepada ummat, sifatnya masih dalam bentuk sajian-sajian umum dari Allah, dan belum dapat dinikmati semua ummat. Agar semua ummat dapat menikmatinya, emas atau hati harus dilebur kembali, dengan peleburannya yang sehalus-halusnya sehinga lebih mudah mencair, sebab pada tahapan ke-4 sifat sajian-sajian hati masih sering menampakkan hal-hal yang kasar.

\section{Tahapan Radhiyah}

Ini tahap penerimaan apa adanya tanpa protesan pada Sang Pemberi. Tahapan ini diibaratkan emas atau hati harus dilebur kembali dengan syarat. Apapun cara yang dilakukan oleh si tukang emas atau si tukang hati (yang mencairkan emas atau hati), sang emas atau sang hati harus serba ridha menerima. Inilah yang dikatakan masuk dalam tahapan ke-5 yaitu proses radhiyah. Di sinilah hati benar-benar akan mencair halus. Hati atau emas yang telah mencair, akan mudah dibentuk dengan bentukan yang diinginkan atau sekehendak-Nya.

\section{Tahapan Mardhiyah}

Setelah terbukti diri serba menerima atau ridha, maka diri mendapatkan keridhaan-Nya. Tahapan ini diibaratkan, setelah emas atau hati menjadi cair; masuklah pada tahapan pembentukan emas atau hati menjadi tampilan keindahan Allah. Inilah tahapan ke-6 yaitu proses mardhiyah atau jenjang tempat Allah menjatuhkan keridhaan pada hati seorang hamba. Dengan telah terbentuk keindahan hati, apapun yang disajikan hati semua ummat dapat menikmatinya. Dengan gambaran demikian ini, dapatlah seseorang mengetahui akan keberadaan hatinya. Jika apa-apa yang disampaikannya belum dapat dinimati ummat banyak, bahkan sebaliknya tidak jarang ummat beranggapan apa-apa yang disampaikan laksana burung berkicau, pertanda hatinya belum mendapat keridhaan Allah. Apa-apa yang ia perbuat dan katakan masih dasarnya dorongan dari keinginan dirinya. Tetapi jika hati telah Allah ridhai dengan sendirinya semua fihak mudah tertegun akan segala ucap dan perbuatannya. Bagi emas pada proses tahapan ke-6, yaitu menjadikan emas dalam bentuk perhiasan. Semua manusia menyukai, bahkan akan diupayakan untuk mendapatkan perhiasan tersebut. Di tahapan ke-6 inilah tampak perbedaan nyata antara sajian hati yang telah Allah ridhai berupa keilmuan-keilmuan murni dengan ilmu-ilmu manusia yang hanya mendapat pengesahan logika dan yang menyetujuinya hanya sebatas makhluq. IImu-ilmu manusia yang disahkan logika belum dan tidak akan mendapat persetujuan dari Allah, hanya ilmu-ilmu dari hati sajalah yang mendapat pengesahan dari Allah. Sederetan gelar kesarjanaan ilmu yang telah diraih oleh siapapun, jika ilmunya belum dapat mengubah "taraf hidup ummat" atau "taraf hidup sosial" dalam pengertian bukan sebatas materi melainkan ruhani, kesemuanya itu belum bermakna dalam pengertian sempurna. 


\section{Tahapan Kamilah}

Tahapan tertinggi adalah kesempurnaan. Tahapan ini, ibarat emas perlu dibalut atau dipatri dengan batu-batu permata indah, agar tampak kemewahan nilai perhiasan emas. Begitu pula hati tidak saja sebatas dilingkari rahmat, tetapi hati harus dibalut dengan keindahan-keindahan Asma Allah atau bahasa seorang arif: "dirinya telah berselimutkan pakaian Asma Keindahan Allah". Inilah proses akhir emas atau hati di tahapan ke-7, yaitu tingkat kamilah, sebagai nilai kesempurnaan perjalanan hati/ruhani seorang hamba. Segala macam bentuk kekayaan hati ada di dalam tahapan ke-7. IImunya bukan saja terbatas pada yang nyata (menurut mata), tetapi di balik nyata pun akan tersingkap tanpa hijab. Demikian gambaran proses pengolahan emas sejak dari bercampur baur dengan batu dan pasir, hingga berbalutkan batu-batu permata indah.

\section{Juz Manusia}

Tiga kali 40 hari setelah konsepsi terjadi, ruh manusia ditiupkan. Bersamaan dengan ditiupkan ruh itu, ditetapkan pula juz manusia. Oleh karena itu juz pribadi baru dapat diketahui setelah bayi berusia 4 bulan di dalam kandungan ibunya. Jadi juz pribadi tidak dilihat berdasarkan nama dan tanggal kelahiran seperti kebiasaan dugaan orang. Sebelum lahir dan sebelum diberi nama, dengan izin Allah juz pribadi dapat dikenali.

Tilikan mengenai juz manusia menyangkut potensi dasar yang bersifat menetap dan varian perubahannya. Juz menyediakan informasi mengenai pola pandang dan pikir seseorang, sifat-sifat dasar, dan pengalaman tertentu yang pasti dilewati seseorang dalam kadar yang bervariasi. Pemahaman terhadap juz ini merupakan pemahaman terhadap rancangan sifat dan perbuatan seseorang yang telah terjadikan dan yang dapat terjadi. Dengan pengetahuan terhadap rancangan ini, upaya pendidikan dapat dirancang secara lebih relevan sesuai dengan dasar potensi yang dimiliki seseorang. Sekaitan itu, upaya pendidikan, termasuk konseling, dapat lebih efisien untuk membantu seseorang mengembangkan sisi positif dan meminimalkan sisi negatif berdasarkan juz pribadi.

Ada dimensi juz yang tidak berubah dan ada dimensinya yang dapat berubah karena pengalaman atau pengaruh lingkungan. Namun begitu perubahan yang terjadi tetap dalam kerangka sifat dasar juz yang bersangkutan. Sebagai contoh manusia dengan juz yang memiliki sifat dasar air (simbol Surah Yunus) pasti memiliki sifat dasar sebagaimana air: ingin memenuhi semua ruang (seakan mampu dalam segala hal), bersifat dingin menyejukkan (dapat menjadi panas, namun akan kembali dingin lagi ketika faktor pemanasnya hilang), yang bergerak aktif cenderung lebih sehat daripada yang tergenang, dapat menanjak menaik melalui kekuatan dorongan dan penambahan volume kekuatan (turun 
kembali ketika tenaga dorongnya melemah), lunak-lentur-luwes namun dapat pula menjadi mengeras ketika membeku. Ketika faktor pembeku hilang, air akan kembali mencair. Seseorang dengan dasar jiwa air bisa saja marah, namun dalam kemarahannya tidak sebagaimana seseorang dengan jiwa gunung berapi (Simbol Nabi Ibrahim/Surah Ibrahim) ataupun petir (Ar-Ra'du). Seseorang dengan dasar jiwa petir cenderung berbicara melompat-lompat dengan nada tinggi-rendah, tindakannya sulit diduga dan sering mencemaskan pihak lain, suka menyembunyikan diri dan cenderung sulit diatur, namun mudah menguasai segala keterampilan. Pola dasar demikian itu dapat diubah melalui pendidikan, namun pada saat tertentu pola yang asli terlihat juga.

Juz manusia difahami dalam kerangka 4 komponen juz: dasar jiwa (inti dasar), penonjolan sifat, kekuatan dan kelemahan, dan jalan keluar. Dasar jiwa tersimpulkan dari halaman ke 16 pada setiap juz (kecuali juz 1 dan 30). Ini merupakan bagian pribadi yang menjadi dasar corak sifat dan perilaku seseorang, karakter dasar ini tidak berubah, hanya bisa tertutupi. Penonjolan sifat tergambarkan dari halaman 1 sampai dengan 6 . Bagian ini berisi sejumlah sifat yang mengedepan dibandingkan sifat-sifat yang lain. Ada variasi pada orang dengan juz yang sama namun tetap dalam kerangka wadah sifat-sifat pada juznya. Kekuatan dan kelemahan terdapat pada halaman 7 sampai dengan 13. Ada sejumlah sifat yang apabila terbina akan menjadi kekuatan, sebaliknya apabila tidak terbina dengan baik berubah menjadi kelemahan seseorang. Kelemahan ini menjadi faktor seseorang bermasalah. Ketika masalah terjadi, yang diperlukan adalah penyelesaian masalah. Untuk itu diperlukan jalan keluar, penanganan oleh diri, dan bantuan penanganan. Jalan keluar atas permasalahan ini rahasianya tersembunyi pada halaman 14 dan 15 pada setiap juz.

\section{Model Konseling Berbasis Juz}

Konseling adalah bagian dari proses pendidikan yang memandang konseli sebagai pribadi yang memiliki potensi fithri sesuai dengan ketetapan juz pribadinya. Konseli ini memerlukan pertolongan dalam pemahaman dan pengembangannya menuju kesempurnaan penjadiannya sebagai insan kamil.

Konseli hadir dengan latar belakang kebutuhan dan permasalahan hidup yang bervariasi. Pertolongan yang diberikan semestinya memberikan jaminan kesesuaian dengan potensi fithri yang menentukan pola pandang-sikap-perilaku dan rancangan ketetapan jalan hidupnya. Tanpa memperhatikan kepastian pola dan rancangan yang khas pada pribadi tertentu, peluang keberhasilan kurang bisa diharapkan. Konseling berbasis juz menyediakan kerangka kerja untuk menolong konseli sesuai dengan pola pandang-sikap-perilaku dan rancangan ketetapan jalan hidupnya. Melalui kerangka kerja yang demikian itu, selain peluang keberhasilan menjadi lebih besar. dapat pula mengefisienkan proses. 
Konseling berlangsung melalui proses partisipatif, konselor dan konseli sama-sama aktif. Konselor berkualifikasi memahami struktur juz dan dinamika pada manusia. Pemahaman sekurang-kurangnya menyangkut makna surah yang ada pada setiap juz, dan makna surah terkait dengan struktur formatnya. Tugas konselor membimbing, mengajar, memberikan arahan dan isyarat untuk memperoleh pemahaman diri dan apa yang perlu diperbuat oleh konseli, memotivasi, merancang bersama, menasihati, dan menyepakati tugas-tugas bagi konseli, serta membantu memeriksa kemajuan.

Konseli aktif dalam proses dialogis selama pertemuan konseling, aktif menelusuri isyarat dan makna yang tergelar pada juz pribadinya, melakukan restrospeksi dengan panduan juz, melaksanakan tugas-tugas yang disepakati, dan berlatih mengembangkan perilaku yang diperlukan.

Selama proses konseling, konselor menerapkan prinsip-prinsip komunikasi efektif. Konselor menerapkan prinsip dan teknik perkataan yang berterima secara baik (qaulan ma'rufa) dan mudah untuk dimengerti (qaulan maisyura). Dalam penggunaan secara tepat, konselor penerapkan prinsip dan teknik komunikasi yang membekas (qaulan baligha), perkataan yang halus-bersayap (qaulan layyina), dan perkataan yang tandas tak terbantahkan (qaulan syadida).

\section{Tahapan Konseling}

Proses olah lanjut konseling ditempuh melalui lima tahapan sebagai berikut: Ta'rifi (Arifi)

Ini merupakan tahap pengenalan/pengidentifikasian juz pribadi konseli. Pengidentifikasian juz ini mutlak berada pada wilayah spiritual, karena itu hanya dapat ditempuh melalui jalur spiritual juga (spiritual bil qalbi). Mengenali ketetapan juz seseorang tidak bisa dipelajari, kecuali menggantungkan pada kehendak-Nya semata melalui pemberian-Nya (yang bisa dipelajari karakteristiknya). Hanya saja, setiap manusia telah diberi fasilitas untuk menampung pemberian, yaitu hati. Agar hati memilki kesiapan untuk menampung pemberian sehingga dikehendaki untuk diberi, manusia perlu menjaga agar hati itu tetap dalam keadaan bersih murni dari kepentingan (qalbun salim).

Konselor perlu memeriksa dirinya, telah sampai pada tingkatan yang dimaksud ataukah belum. Apabila kemampuan untuk mengenali juz pribadi seseorang belum ada, konselor perlu bekerjasama dengan orang yang telah diberi kemampuan. Konselor juga dapat merujukkan konseli pada orang yang dimaksud, sebagaimana lazimnya konselor merujukkan seseorang untuk mendapatkan layanan pemeriksaan psikologis. 


\section{Arafa fiy}

Hasil pengenalan juz didalami atau dieksplorasi kedalaman dan keluasannya untuk mempertajam pemahaman diri. Pendalaman merupakan langkah penilikan aspek-aspek pribadi yang mencakup: pengalaman hidup, sifatsifat pribadi, persepsi terhadap situasi yang mungkin terjadi, kekuatan diri, dan keterbatasan diri. Penilikan aspek-aspek pribadi konseli ini didasarkan pada isi, makna, isyarat, dan rumus-rumus Qurani. Pemahaman yang diperoleh dapat memberikan kepastian akan "siapa diri saya". Dapat dikatakan sebagai kepastian karena yang terungkap telah diperkuat dengan bukti-bukti nyata.

Bukti nyata itu diperoleh melalui pencocokan pengalaman hidup konseli dengan isyarat Qurani sesuai dengan juz yang bersangkutan. Seperti seseorang yang memiliki unsur air pada juznya (disimbolkan Surah Yunus) dipastikan pernah tenggelam atau hampir tenggelam di air. Juz 13 sering mengalami kram pada kaki, juz 14 sering sakit di daerah belikat, juz 15 sakit pada persendian, juz 28 mudah terserang migraen ataupun vertigo, dan seterusnya.

\section{Taufiqi}

Pemahaman terhadap karakteristik diri dan prinsip-prinsip kebenaran dan kesetimbangan tidak dengan serta merta menjadikan seseorang memilih jalan untuk menyeleraskan dirinya. Perlu keyakinan akan kebenaran nilai dan isi juz. Untuk sampai pada keyakinan biasanya perlu bukti nyata melalui penelusuran dan pembandingan antara bahan ideatik dari juz dan pengalaman empirik yang bersangkutan. Sepanjang pencocokan pengalaman hidup yang positif, pada umumnya konseli mudah menerima. Misalnya ketika dikatakan, "apakah Anda sering mengalami, ketika malam bermimpi, pada siangnya atau dalam waktu dekat menjadi kenyataan?" Untuk hal-hal yang dipandang negatif sebagian konseli berusaha menutup diri. Seperti saat ditanya. "Apa benar Anda sering berbeda pendapat dengan ayah Anda, sekalipun tidak dinyatakan secara langsung, hanya disimpan di hati?" contoh lain berkenaan dengan pengungkapan ketidaksabaran seseorang, sebagian menyatakan tidak merasakannya. Hal demikian ini memerlukan pengungkapan dengan cara lain yang lebih bisa diterima.

Sebagian konseli sudah merasakan terganggu dengan apa yang dialaminya. la berinisiatif untuk konseling dengan harapan ada bantuan penyelesaian atau menemukan jalan keluarnya. Dalam kasus demikian, secara terbuka ia akan mengungkap segala pengalaman negatif dan sifat-sifat buruknya. Konselor perlu membantunya untuk merancang rencana perilaku baru (langkah awal) agar konseli terbebas dari masalah yang membelenggunya. Sebagian yang lain menunjukkan keputusasaan dan keraguan apakah keadaannya masih bisa diperbaiki. Jika demikian halnya, maka konselor perlu membangkitkan kembali 
keyakinan dan semangat hidupnya, bahwa ia masih memiliki kekuatan dan kesempatan untuk membangun kehidupan yang lebih baik. Perbaikan (ishlah) mencakup aspek ubudiyah (ritual ibadah yang berdampak secara internal dan eksternal) dan aspek muamalah (ibadah yang terkait langsung dengan hubungan antarmanusia dan alam sekitar). Untuk itu, tetap diperlukan penyesuaian tingkat kemampuan konseli dengan pilahan rancangan perilaku barunya.

Fi'li

Pemahaman yang telah mendapatkan pencocokan diri dan rancangan perilaku baru yang telah dibuat perlu diwujudkan pada tindakan nyata. Langkah nyata mewujudkan rancangan (langkah awal) memerlukan semangat kuat (azam) yang diiringi dengan tawakal. Jadwal perbaikan diri (ishlah) dijalani secara disiplin dan dilazimkan (istiqamah) sehingga diperoleh perubahan yang nyata. Selama tahap ini tidak jarang konseli memerlukan dukungan, mengalami pelemahan semangat, dan memerlukan penegasan akan apa yang terjadi dan perlu dilangkahlanjutkan. Komunikasi singkat melalui media komunikasi, pada umumnya dapat membantu konseli untuk tetap bertahan pada garis rencana perubahan dirinya. Sintem dukungan juga perlu dikelola secara baik dan terpadu untuk kemudahan mewujudkan amal perbuatan.

Ihtisabi

Ini merupakan langkah monitoring dan evaluasi. Memantau dan mengevaluasi langkah nyata dapat dilakukan oleh konselor. Namun lebih menjamin kebaikannya jika konseli dibantu untuk mampu memantau, mengukur dan mengevaluasi sejauh mana langkah awal telah dilangkahnyatakan. Sebagian konseli terlalu memandang rendah terhadap kemajuan yang ia peroleh. Untuk itu konselor perlu membantu konseli untuk membangun wawasan bahwa ada kalanya perbaikan itu bergerak secara berangsur bermula pada bagian yang kurang jelas untuk dapat diamati. Keajegan diperlukan untuk sampai pada kebahagiaan melihat bukti nyata dari langkah perbaikan.

\section{Teknik-Teknik Konseling}

Selain teknik dasar dalam konseling, yaitu teknik-teknik komunikasi qurani, melalui metode HAQ dapat ditelusuri sejumlah teknik pengubahan yang tergali dari Al-Qur'an. Beberapa di antaranya:

Anbai, penginformasian: merupakan teknik dasar, yaitu menyajikan dan membahas informasi penting dan bermutu untuk memperoleh pemahaman dan kejelasan langkah perbaikan diri.

Amtsal/matsal, perumpamaan: menyajikan percontohan metaforik yang bermakna, seperti penggambaran perbuatan sia-sia sebagai tanah di atas batu 
ditiup angin, dan mencauk air dengan telapak tangan terbuka; kebermanfaatan digambarkan sebagai pohon yang baik, tumbuhnya benih yang ditanam, dan lainlain

Iqrai, membaca: sebagai perintah Al-Quan yang pertama kali turun kepada Rasulullah saw adalah membaca. Membaca Al-Qur'an secara tartil dan memahami terjemahan dan makna dapat ditugaskan dan dijadwalkan pada konseli.

Riyadhah, berlatih menuju kesempurnaan: melangkah nyatakan rancangan dengan mengistiqamahkan jadwal perbaikan, seperti terkait pengendalian nafsu, pengelolaan emosi, dan lain-lain.

Uswah, keteladanan: memberikan contoh kasus dan langkah nyata perbuatan kebajikan baik secara langsung maupun tidak langsung.

Qishashi, penyajian kisah: membahas cerita inspiratif baik yang negatif maupun yang positif untuk dapat diambil pelajaran dan hikmahnya.

Al-alati, media: penggunaan media gambar dan benda dapat mempermudah pemerolehan pemahaman dan melancarkan pelangkahnyataan rancangan pengubahan. Untuk itu perlu dipilih media yang sesuai dengan kebutuhan dan kecocokannya bagi konseli.

Perbandingan: menyajikan penggambaran dan bahan perenungan yang mencerahkan, seperti ajuan pertanyaan dalam Al-Qur'an, "Samakah yang melihat dengan yang buta?", "Apakah sama antara yang gelap dan yang terang?"

Teknik-teknik pengubahan perilaku di atas penerapannya perlu disesuaikan dengan tipologi seseoerang berdasarkan juz pribadinya. Misalnya, konseli yang menyukai bahasa-bahasa diplomatis ditritmen dengan teknik yang mengandung unsur metafora, sedangkan lainnya yang menyukai ketegasan dengan informasi atau pembimbingan langsung dan lugas.

\section{SIMPULAN}

Berdasarkan bahasan di atas dapat disimpulkan Al-Qur'an memiliki pandangan yang tersendiri mengenai manusia dengan potensi-potensi dasar dan perbedaan individualnya. Perbedaan individu didasarkan pada karakter juz yang ada pada Al-Qur'an. Untuk itu konseling yang efektif perlu mendasarkan diri pada perbedaan individual sesuai juz pribadi konseli. Konseling demikian itu disebut sebagai konseling berbasis juz qurani yang memiliki langkah-langkah dan teknik khusus bagi pelaksanaannya. Sebagai gagasan yang baru model konseling ini perlu diseminasi secara meluas dan penerapan secara intensif sehingga dapat dikenali tingkat keefektifannya. 


\section{REFERENSI}

Capra, F. (1999). Titik balik peradaban (M. Thoyyibi, Trans.). Yogyakarta: Yayasan Bentang Budaya. (The Turning Point: Science, Society, and the rising culture. Original work published 1982).

Ki Moenadi MS. (1998a). Bahasa kwalitatif-kwantitatif di dalam Al-Qur'an. Malang: Yayasan Badiyo.

Ki Moenadi MS. (1998b). Belajar menimba pelajaran ke dalam diri manusia. Malang: Yayasan Badiyo.

Ki Moenadi MS. (1999). Pengembangan daya bakat kemampuan manusia. Malang: Yayasan Badiyo.

Ki Moenadi MS. (2000). Ukuran pasti kepribadian manusia. Malang: Yayasan Badiyo.

Ki Moenadi MS. (2000a). Keilmuan pasti dari juz/bagian tertentu: Seri 1. Malang: Yayasan Badiyo.

Ki Moenadi MS. (2000b). Keilmuan pasti dari juz/bagian tertentu: Seri 2. Malang: Yayasan Badiyo.

Othman, A. I. (1981). Manusia menurut Al-Ghazali. Bandung: Pustaka.

Thoha, M. (2004). Paradigma baru ilmu pengetahuan sosial dan humaniora. Jakarta: TERAJU.

Yahdi, M. (2010). Fungsi pendidikan dalam kehidupan manusia. Lentera Pendidikan, 33(2), 211-225. 